\title{
Reclaiming matrilineal traditions and building Girl Societies in indigenous Montana
}

Kelly Hallman

Population Council

Eva Roca

Stephanie Martinez

Follow this and additional works at: https://knowledgecommons.popcouncil.org/departments_sbsr-pgy How does access to this work benefit you? Let us know!

\section{Recommended Citation}

Hallman, Kelly, Eva Roca, and Stephanie Martinez. 2020. "Reclaiming matrilineal traditions and building Girl Societies in indigenous Montana," IMAGEN Brief no. 5. New York: Indigenous Adolescent Girls' Empowerment Network (IMAGEN). 


\section{Reclaiming Matrilineal Traditions \& Building Girl Societies in Indigenous Montana}




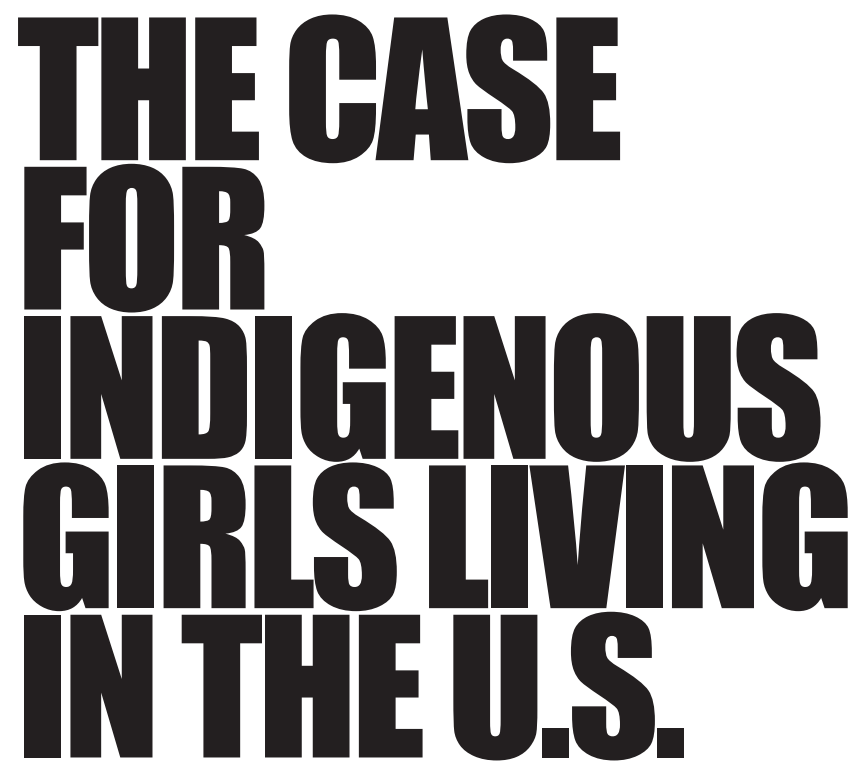

The journey through adolescence is rarely smooth for anyone, but for girls around the world, the data show that the path between girl- and womanhood can be particularly fraught with life-changing traumatic experiences. A girl's accessible physical world shrinks as she gets older, and she is more likely to face tumultuous transitions than adolescent boys. This is as true for girls living in resource-poor nations across the globe as it is for indigenous girls living in the U.S.

Being an Al female in the US carries with it a rich cultural history and heritage that shines a bright light on their strength and potential. Historical repression combined with modern overregulation of and under-investment in their communities however have resulted in their facing particular risks. 1 in 3 American Indian women report having been sexually assaulted in her lifetime (often by non-Native attackers), and American Indian females have fewer financial assets and skills than their Al male counterparts. Native youth bear a high burden of suicide and violence, with Al girls being at high risk for sexual violence, trafficking, and teen pregnancy.



Montana is host to a rich tapestry of indigenous ancestry. The Blackfeet, Crow, Flathead, Fort Belknap, Fort Peck, Northern Cheyenne, and Rocky Boy Reservations comprise the federally-recognized reservations, and the Little Shell Tribe of Chippewa Indians are recognized by the state of Montana, though not yet federally. These lands and urban centers are home to the people of the Blackfeet Nation, the Chippewa Cree Tribe, the Confederated Salish and Kootenai Tribes, the Crow Nation, the Fort Belknap Indian Community, the Fort Peck Assiniboine and Sioux Tribes, the Little Shell Chippewa Tribe, and the Northern Cheyenne Tribe.

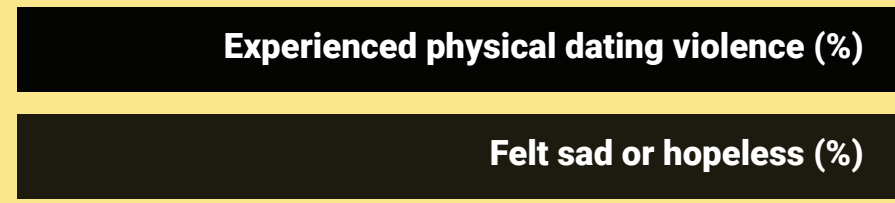

Seriously considered attempting suicide (\%)

Currently smokes cigarettes

Ever used methamphetamines (\%)

Had sex for the first time before age 13

Skipped breakfast (in the week before the survey)
Montana also has the devastating distinction of currently holding the nation's highest suicide rate. The data generated from the 2017 Montana High School Youth Risk Behavior Study below provides some insight into this troubling pattern, not only through the lens of adolescent girls in Montana, but through the comparative experiences of Native girls and their white counterparts. In the survey, Native girls were nearly twice as likely to have experienced physical dating violence compared to White girls, and reported a higher rate of feeling sad or hopeless. Native girls were also more likely to have had sex for the first time before age 13 , and to have skipped breakfast in the week prior to the survey.



Experiences of Risk among and White Adolescent Girls in Montana

\author{
(Montana High School \\ Youth Risk Behavior \\ Survey, 2017)
} American Indian 


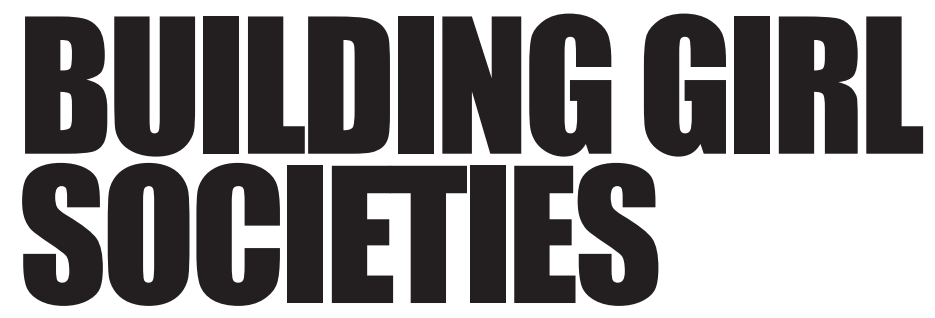

On March 26 and 27, 2019, the Indigenous Adolescent Girls' Empowerment Network (IMAGEN) co-hosted a workshop with the Little Shell Band of Chippewa Indians in Great Falls, Montana. Funded by the Montana Healthcare Foundation, this meeting brought together representatives from each of the 7 reservations, as well as 2 urban Indian centers.

IMAGEN, headquartered at the GIRL Center in New York City, is a nativefemale designed, led, and controlled network that adapts, builds, and shares innovative skills and tools to address the needs of adolescent girls. Building off of decades of programmatic research and lessons learned, IMAGEN brings locally-led indigenous organizations together to propose innovative ways to reclaim female social infrastructure and matrilineal traditions. Through this framework, girl-centered programs adapted to the local context are built to impart important skills, safe havens, and mentor networks to American Indian girls.

Over the course of the two days, youth and adult participants from all corners of Montana's indigenous community took part in facilitated exercises and discussions to understand the transformative potential of applying a girl-centered approach to program design, as well as what a culturally-appropriate local roll-out could look like. Through activities centered around topics such as asset-building, programmatic segmentation, and community mapping, participants identified several regionally-specific vulnerabilities and opportunities that existed for adolescent girls throughout tribal areas in the state.

\section{LOCAL VULNERABILITIES}

- Bullying \& fighting

- Racism \& discrimination

- Drug \& alcohol use

- Self-harm \& suicide

- Early childbearing

- Dropping out of school

- Domestic violence

- Poverty

- No opportunities after school
- Transient, seasonal community visitors

- General community distrust to outside help

- Lack of life preparation

- Programs only during school hours

- Programs more accessible for boys

- Lack of any programs for young people

- Sexual pressure during pow wows

- Lack of community participation

- Rural transportation obstacles

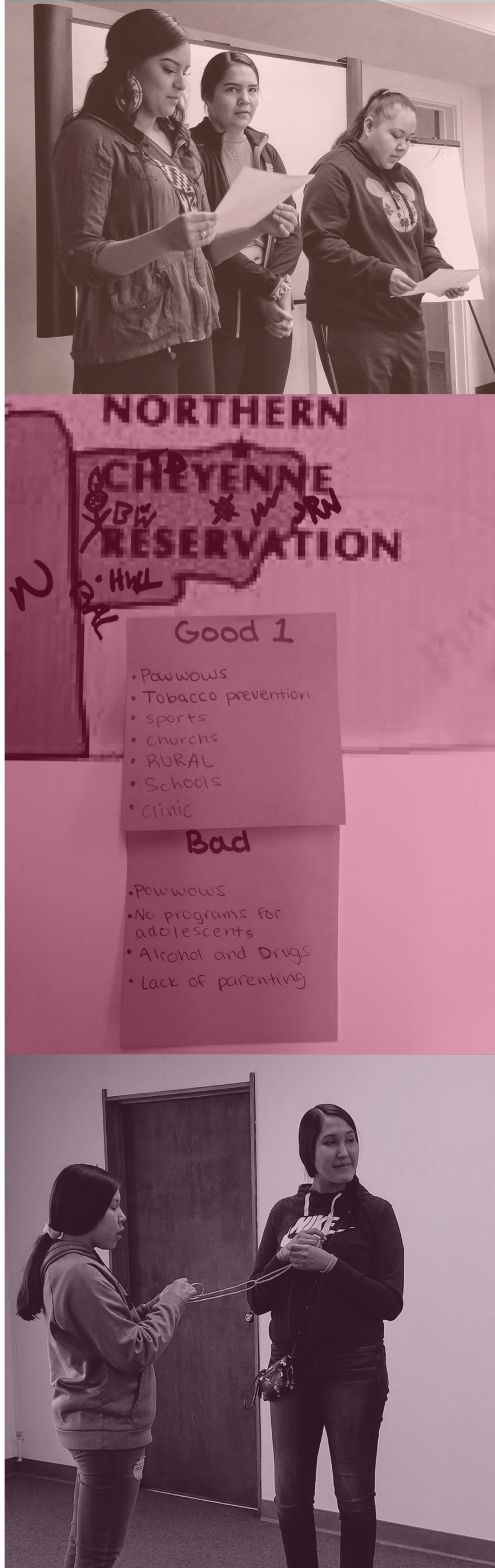




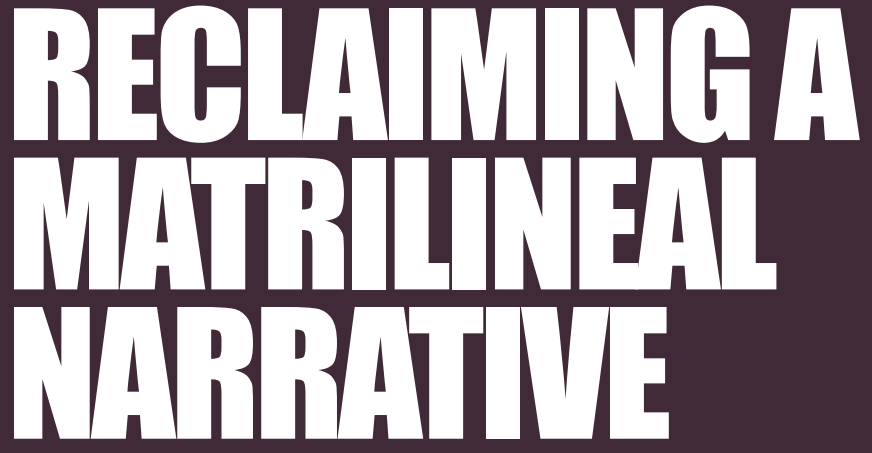

This workshop marked the beginning of a technical assistance dialogue between IMAGEN and local Native organizations in Montana with an interest in adapting and piloting girl-centered programs.

The IMAGEN approach is driven by a fundamental understanding that the most effective way to provide indigenous girls with the assets that they need to successfully navigate adolescence requires reweaving the social fabric of Native communities through a reclamation of matrilineal traditions. IMAGEN aims to do this by establishing neighborhood-level "Girl Societies."

Ideally engaging particularly vulnerable segments of girls between the ages of 10-19 based upon the results of a local-led community diagnostic, these weekly talking circles take place over the course of several months in existing community facilities that are reclaimed as safe spaces. With carefully developed planning tools and culturally-focused content and activities, Native girls learn strategies for success, self-preservation, and leadership while developing meaningful relationships with adult Native women. While the skills the girls learn are designed to serve as assets for handling the difficulties of adolescence in places such as Montana,

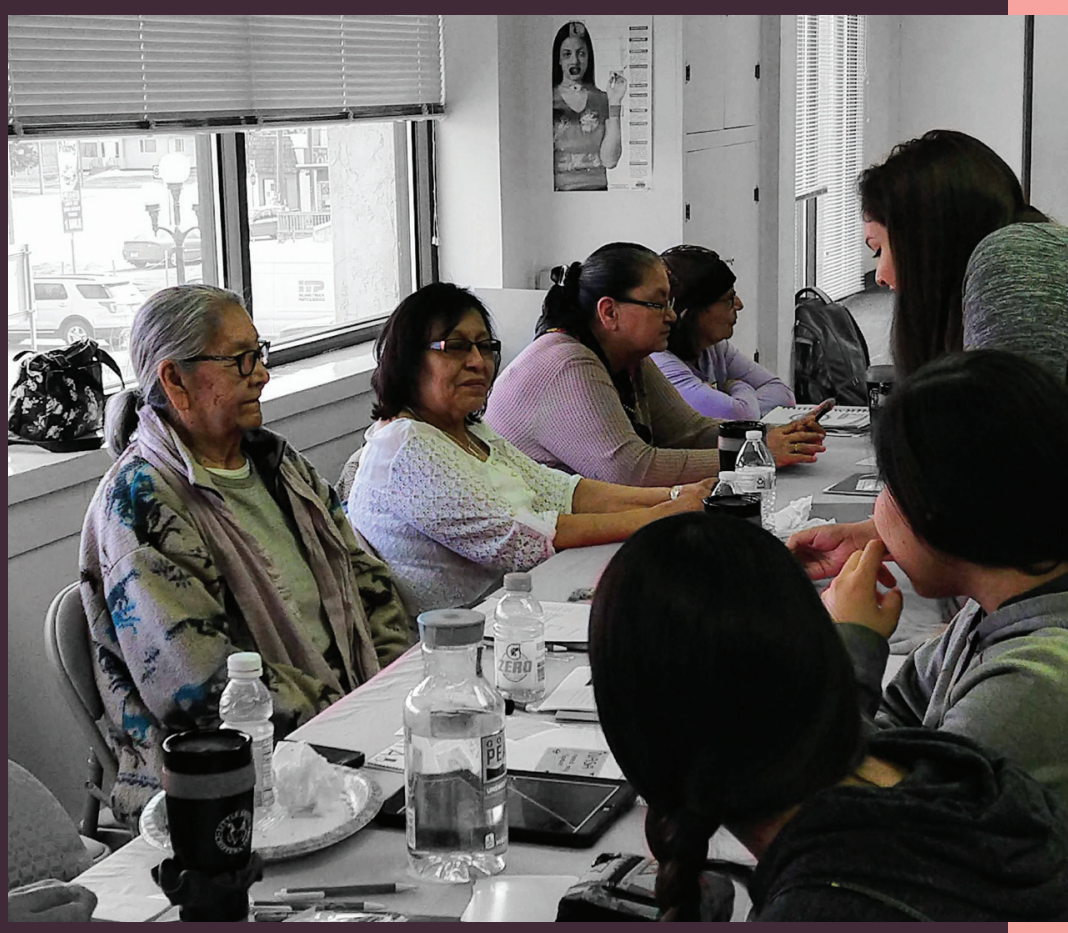

another sobering hope is that the design of these mentorship programs will allow indigenous girls to confront the dangers of the Missing and Murdered Indigenous Women and Girls (MMIWG) crisis. By building skills and providing a physical and social safe haven, engagement in a girl-centered program such as this may be able to provide a girl with an extra circle of support that will know and care if she is missing.

This evidence-based approach is being planned for in other tribal communities in the US. The goal is to raise up and honor the cultural strength and knowledge of Native female elders in order to build the resilience and safety of today's Native teenaged girls.

\section{Organizations represented by participants at the workshop:}

Blackfeet Nation Tribal Health

Boys and Girls Club of Lewistown

Confederated Salish \& Kootenai Tribal Health

Crow Tribe

Fort Belknap Indian Community

Fort Belknap Tobacco Use Prevention

Fort Peck Tribal Health

Helena Indian Alliance

IMAGEN Network

International Tribal Games Society

Little Shell Chippewa Tribe Tobacco Prevention Services

Little Shell Chippewa Tribe Wellness Program

Missoula Urban Indian Health Organization

National Native American Hall of Fame

Northern Cheyenne Tribe

Northern Cheyenne Tobacco Prevention Services

Red Hawk Design

Rocky Boy's Indian Reservation Clinic

State of Montana Tobacco Use Prevention Program

YWCA Missoula GUTS! Program
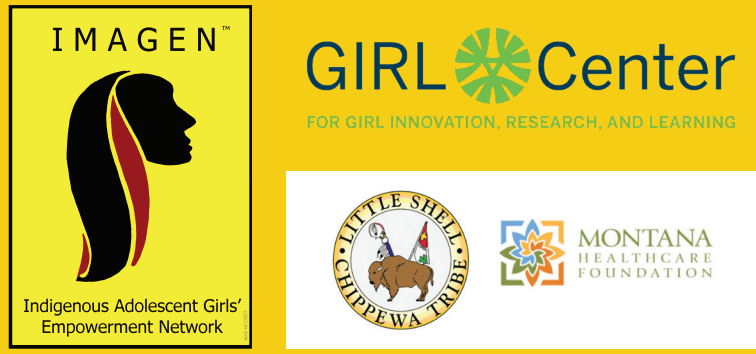

Suggested Citation

Hallman K., Roca E., Martinez S. 2020. Reclaiming Matrilineal Traditions \& Building Girl Societies in Indigenous Montana. NY, NY. Indigenous Adolescent Girls' Empowerment Network (IMAGEN). 